\title{
Srednji volumen trombocita kod karcinoma grkljana - uloga u određivanju stadija karcinoma
}

\section{Mean platelet volume in laryngeal cancer - role in cancer staging}

\author{
Damir Vučinićc ${ }^{*}$, Ivan Vuksan ${ }^{1}$, Tamara Braut ${ }^{2}$, Blažen Marijićć ${ }^{2}$ Gordana Žauhar ${ }^{3}$, \\ Andrea Dekanić, Mira Krstulja ${ }^{4}$, Gordana Zamolo ${ }^{4}$
}

\begin{abstract}
${ }^{1}$ Medicinski fakultet Sveučilišta u Rijeci, Rijeka

${ }^{2}$ Klinika za otorinolaringologiju, kirurgiju glave i vrata, Klinički bolnički centar Rijeka, Rijeka

${ }^{3}$ Katedra za medicinsku fiziku i biofiziku, Medicinski fakultet Sveučilišta u Rijeci, Rijeka

${ }^{4}$ Zavod za patologiju i patološku anatomiju, Medicinski fakultet Sveučilišta u Rijeci, Rijeka
\end{abstract}

Sažetak. Cilj: Ispitati povezanost srednjeg volumena trombocita - MPV (engl. mean platelet volume) s kliničkim stadijem karcinoma grkljana te s histološkim značajkama karcinoma koje mogu činiti podlogu patofiziologije promijenjenog broja te volumena trombocita. Materijali i metode: Retrospektivno su analizirani laboratorijski i klinički podaci 76 pacijenata s patohistološki potvrđenim planocelularnim karcinomom grkljana. Podjelom po kliničkoj TNM klasifikaciji dobivene su dvije skupine: rani i kasni karcinom grkljana. Nadalje, pacijenti su podijeljeni u grupe prema stupnju diferencijacije stanica karcinoma, kao i po prisutnosti vaskularne invazije. Rezultati: Statistički značajna razlika između skupina ranog i kasnog karcinoma u demografskim podacima i podatku o pušenju nije pronađena. Usporedba MPV-vrijednosti pokazala je značajnu razliku $(P=0,003)$ između skupina ranog i kasnog karcinoma grkljana. Nadalje, usporedba istih skupina ukazala je na povećan broj trombocita u skupini kasnog karcinoma grkljana $(P<0,001)$. Uspoređene su skupine podijeljene na osnovi stupnja diferencijacije te je dokazana statistički značajna razlika u MPV-vrijednosti $(P=0,001)$ dok se broj trombocita nije značajno razlikovao $(P=0,132)$. Uspordba MPV-vrijednost između skupina karcinoma s i bez vaskularne invazije pokazala je statističku značajnost $(P<0,001)$. Zaključci: Ovim istraživanjem želimo ukazati na mogućnost korištenja MPV-a u svrhu određivanja kliničkog stadija i prognoze karcinoma grkljana. Određivanje MPV-a lako je dostupna i jeftina metoda koja kliničaru može dati važne informacije.

Ključne riječi: karcinom grkljana; klasifikacija tumora; srednji volumen trombocita

Abstract. Aim: This study aimes to investigate the alteration of MPV (mean platelet volume) in laryngeal cancer. The hypothesis is that different clinical stages of laryngeal cancer and histological characteristics may be the basis of the pathophysiological changes in size and number of platelets. Materials and methods: Laboratory and clinical data were analysed retrospectively from 76 patients with laryngeal squamous cell carcinoma. Two main groups were formed upon TNM clasification: early stage and advanced stage laryngeal cancer. Furthermore, the patients were subdivided according to cancer degree of differentiation and presence of blood vessel invasion. Results: Statisticaly significant difference between early and advanced stage cancer in the demographic and smoking data was not found. The comparison of MPV values showed statistically significant difference $(P=0,003)$ between early and advanced laryngeal cancer. Furthermore, platelet values were significantly higher in the advanced group $(P<0,001)$. The patients with poor differentiated cancer had significantly lower MPV values $(P=0,001)$ compared to the ones with well and moderate differentiated stage. The difference in platelet count in the same groups was not statistically significant $(P=0,132)$. The MPV value was significantly lower $(P<0,001)$ in the group with vascular invasion compared to the group without that cancer characteristic. Conclusions: Our results suggest the possibility of using MPV values to help the clinician in prognosis of laryngeal cancer. Determining MPV values and platelet count is an easily accessible and inexpensive method that provides useful information in everyday clinical practice.

Key words: laryngeal carcinoma; mean platelet volume; tumor staging

http://hrcak.srce.hr/medicina 


\section{UVOD}

Karcinomi grkljana spadaju u najčešće maligne bolesti respiratornog trakta. Spadaju u grupu tumora glave i vrata koji zauzimaju osmo mjesto najčešćih tumora u Europi i SAD-u . U 2013. godini u Hrvatskoj su bila 302 novooboljela (284 muškarca i 18 žena)². Dokazani etiološki faktori za nastanak karcinoma grkljana su pušenje, konzumacija alkohola, izloženost azbestu, ostale kronične bolesti respiratornog sustava i pojedine bolesti probavnog sustava poput gastroezofagealnog refluksa ${ }^{3,4}$. Heterogenost kliničke slike i ponašanja tumora uvelike određuje sama anatomija grkljana. Karcinomi glasnica ranije se dijagnosticiraju zbog brže pojave simptoma za razliku od onih primarno smještenih u supraglotičnoj i subglotičnoj regiji. Klinička slika supraglotičnih karcinoma može biti nejasna, često s kasnim simptomima. Disfagija, bol u uhu i dispneja javljaju se u kasnijim fazama bolesti, a zbog obilne limfne drenaže česte su metastaze karcinoma u limfne čvorove vrata. Karcinomi glasnica najčešće se otkrivaju u fazi ranog karcinoma, tipičnim simptomom promuklosti. Klinički stadij određuje se po TNM klasifikaciji (T - tumor, N - limfni čvor, M - metastaza). Histopatološki $85 \%$ karcinoma grkljana su planocelularni karcinomi. Neki od jasnih prognostičkih faktora su histološka diferencijacija stanica tumora, upalni infiltrat i invazija malih krvnih žila ${ }^{1}$. Imunohistokemijska analiza biomarkera, kao što su panCitokeratin, Ki-67 i p53, koristi se za procjenu prognoze i proliferacije karcinoma ${ }^{5}$. U posljednje vrijeme naglasak je na istraživanju povezanosti sistemne upalne reakcije i rasta tumora ${ }^{6}$. Maligne stanice proizvode citokine primarno odgovorne za stvaranje povoljnog mikrookoliša za rast karcinoma. Neki od njih pokreću kaskadu koagulacije i aktivaciju trombocita $^{7}$. Parametar aktivacije trombocita je srednji volumen trombocita (engl. mean platelet volume - MPV). MPV se ispituje u sklopu pretrage osnovne krvne slike i ukazuje na funkciju i aktivaciju trombocita čiji se broj mijenja u upalnim stanjima. Promjene u vrijednosti MPV-a zabilježene su u tumorima debelog crijeva, dojke, sitnostaničnom karcinomu pluća, pločastom karcinomu jednjaka $^{8-12}$. Eryilmaz i sur. navode povećane vrijednosti MPV-a u svim tumorima glave i vrata ${ }^{13}$.
Cilj ovog istraživanja je ispitati povezanost MPV-vrijednosti s kliničkim stadijem karcinoma grkljana, kao i s histološkim značajkama karcinoma, koje bi mogle činiti podlogu patofiziologije promijenjenog broja i volumena trombocita.

Srednji volumen trombocita parametar je pretrage krvne slike koji ukazuje na aktivnost i funkciju trombocita. Promijenjene vrijednosti opisane su kod karcinoma različitih sijela. Iz tog razloga ispituje se mogućnost korištenja ovog parametra kao biomarkera u prognozi i klasifikaciji karcinoma glave i vrata.

\section{MATERIJALI I METODE}

Retrospektivno obrađeni su podaci pacijenata $\mathrm{s}$ karcinomom grkljana liječenih u Klinici za otorinolaringologiju i kirurgiju glave i vrata Kliničkog bolničkog centra Rijeka u razdoblju od listopada 2012. do siječnja 2017. godine. Analizirani su pacijenti s patohistološki potvrđenim planocelularnim karcinomom glasnica. Isključni kriteriji obuhvaćali su: aktivnu hematološku bolest, autoimune bolesti, bolesti jetre, arterijske bolesti te ostale maligne bolesti, uključujući i druga sijela planocelularnog karcinoma glave i vrata. Također, izostavljeni su pacijenti koji su u trenutku dijagnoze bili u terapiji antiagregacijskim ili antikoagulacijskim lijekovima. Nakon probira analizirano je 76 pacijenata koji su podijeljeni u dvije skupine po kliničkoj TNM klasifikaciji. Stadiji 1 i 2 činili su grupu ranog $(n=40)$, dok su stadij 3 i 4 uvršteni u skupinu kasnog ( $n=36$ ) karcinoma grkljana. Klinički, anamnestički i laboratorijski podaci dobiveni su iz baze podataka Klinike. Patohistološki podaci, stupanj diferencijacije i podatak o vaskularnoj invaziji analizirani su iz baze Zavoda za patologiju KBC Rijeka. Podjelom po stupnju diferencijacije (gradus - G) dobivene su tri skupine: dobro diferencirani karcinomi - G1 ( $\mathrm{n}=$ 11), umjereno diferencirani - $G 2(n=49)$ i slabo diferencirani karcinomi - G3 $(n=16)$. Nadalje, pacijenti su na osnovi podatka o vasklarnoj invaziji podijeljeni u dvije skupine, 47 karcinoma nije pokazivalo proboj u male krvne žile, dok ih je kod 29 utvrđena vaskularna invazija. Uzorci krvi izvađeni su svakom ispitaniku punkcijom vene uz dodatak EDTA (engl. ethylenediaminetetraacetic acid - 
EDTA). Referentne vrijednosti laboratorija korištene za usporedbu podataka su: MPV 6,9-10,4 fL i broj trombocita $150-400 \times 10^{9} / \mathrm{L}$. Pretraga krvne slike za sve pacijente rađena je prije operativnog zahvata ili druge terapije karcinoma.

\section{Statistika}

Za statističku obrada podataka korišten je računalni program Statistica version 13.1 (StatSoft, Inc. OK, USA). Prikazane su relativne frekvencije i mjere središnjice. Nadalje, ispitna je normalnost raspodijele po grupama. U usporedbama vrijednosti MPV-a između skupina podijeljenih na osnovi kliničkog TNM stadija i skupina na osnovi podatka o vaskularnoj invaziji, korišten je Studentov t-test zbog normalne raspodjele vrijednosti. Usporedbe istih skupina u broju trombocita vršene su neparametrijskim Mann-Whitneyjevim U-testom. Za usporedbu MPV-a prema stupnju diferencijacije karcinoma korištena je analiza varijacije i Sheffe test, dok je Kruskal-Wallisov test korišten za usporedbu broja trombocita $u$ istih skupina. U obzir kao statistički značajne uzete su $P$ vrijednosti manje od 0,05 $(P<0,05)$.

\section{REZULTATI}

Demografski podaci prikazani su u tablici 1. Usporedba skupina ranog i kasnog karcinoma prema dobi pacijenata u trenutku dijagnoze $(P=0,431) \mathrm{i}$ podatku o pušenju nije pokazala statistički značajnu razliku. Usporedba prema MPV-vrijednostima pokazala je da postoji statistički značajna razlika ( $\mathrm{t}=3,54 ; P=0,003$ ) između skupina ranog i kasnog karcinoma grkljana (tablica 1; slika 1). Također, usporedba istih skupina prema broju trombocita ukazivala je na statistički značajnu razliku ( $U=381 ; P<0,001$ ) (slika 2). Usporedba MPV-a prema stupnju diferencijacije pokazala je statistički značajnu razliku ( $F=7,42 ; P=0,001)$. Podrobnije je post-hoc analizom Sheffe testom potvrđeno da se po MPV-vrijednosti statistički značajno razlikuju skupine G1 i G3 te skupine G2 i G3 (tablica 2; slika 3). Nadalje, nije dokazana statistički značajna razlika $(\mathrm{H}=4,04 ; P=0,132) \mathrm{u}$ broju trombocita istih skupina (slika 4). Usporedba MPV-vrijednosti između skupina karcinoma sa i bez vaskularne invazije pokazala je da postoji statistički značajna razlika ( $\mathrm{t}=4,54 ; P<0,001$ ).

Tablica 1. Usporedba podataka skupina ranog i kasnog karcinoma grkljana

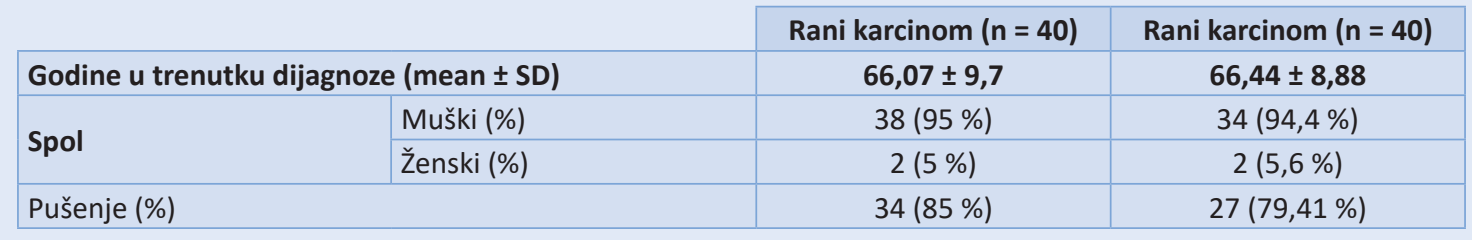

SD - standardna devijacija, MPV - engl. Mean platelet volume

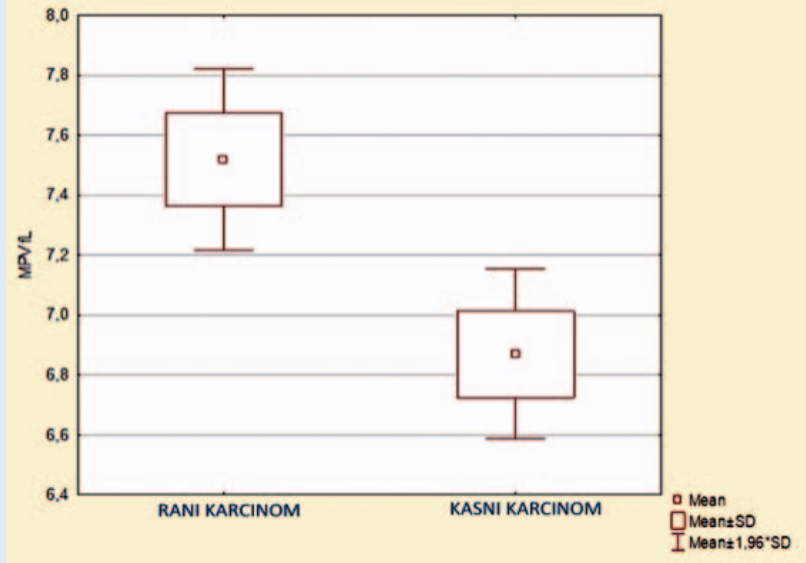

Slika 1. Usporedba MPV-vrijednosti između skupina ranog i kasnog karcinoma grkljana

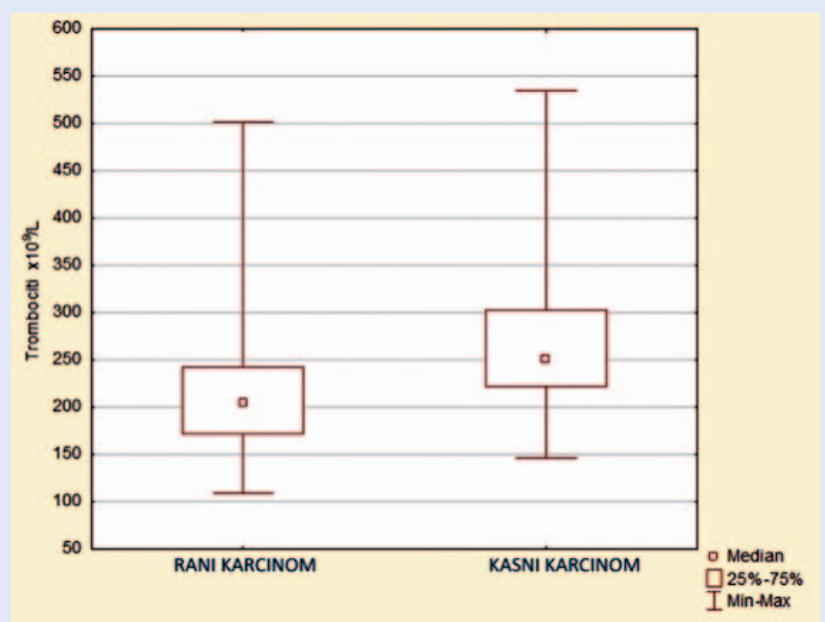

Slika 2. Usporedba broja trombocita između skupina ranog i kasnog karcinoma grkljana 
Tablica 2. Usporedba vrijednosti MPV-a kod pacijenata podijeljenih po stupnju diferencijacije karcioma

\begin{tabular}{|c|c|c|}
\hline Stupanj diferencijacije & Broj pacijenata (\%) & MPV (mean \pm SD) \\
\hline G1 & $11(14,47 \%)$ & $7,91 \pm 1,03$ \\
\hline G2 & $49(64,47 \%)$ & $7,26 \pm 0,88$ \\
\hline G3 & $16(21,06 \%)$ & $6,56 \pm 0,85$ \\
\hline Odnos između skupina & \multicolumn{2}{|c|}{ Izražena $p$ vrijednost } \\
\hline G1 - G2 & 0,109 \\
\hline G2 - G3 & 0,032 \\
\hline G1 - G3 & 0,001 \\
\hline
\end{tabular}

G - gradus (stupanj diferencijacije); SD - standardna devijacija

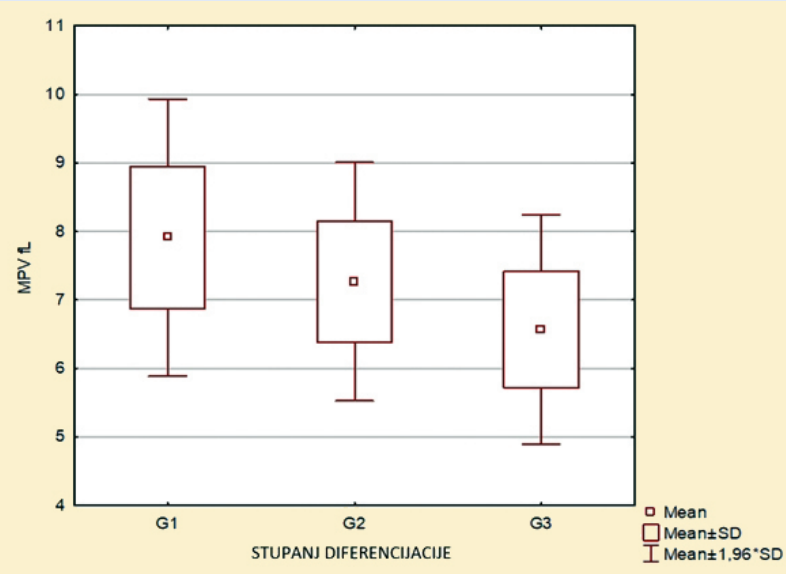

Slika 3. Usporedba vrijednosti MPV-a kod pacijenata s karcinomom grkljana različitih stupnjeva diferencijacije

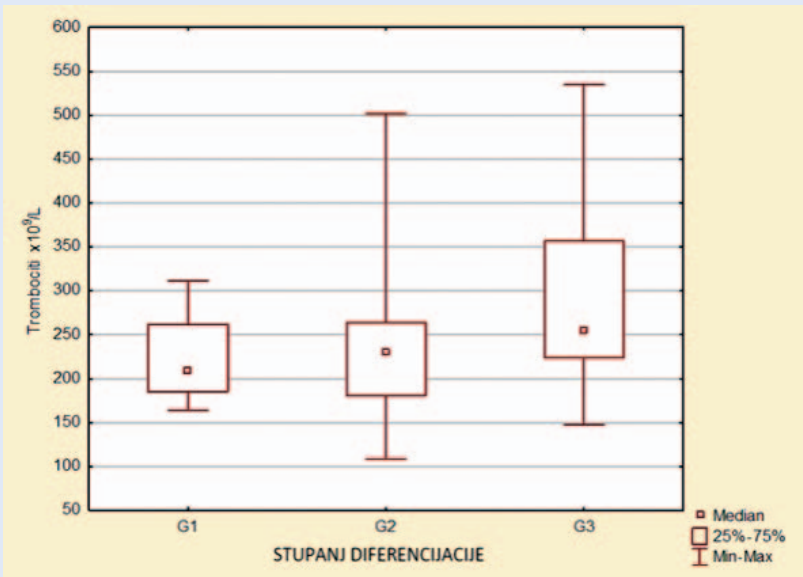

Slika 4. Usporedba broja trombocita po stupnju diferencijacije karcinoma
Mean vrijednosti MPV-a u skupini s vaskularnom invazijom bio je 6,63 fL, dok je u skupini bez invazije iznosio 7,56 fL (slika 5). No, u posljednje spomenutim skupinama nije bilo statistički značajne razlike u broju trombocita $(P=0,939)$.

\section{RASPRAVA}

Brojne studije dokazale su promjene u MPV-u i broju trombocita kod pacijenata s karcinomima različitih primarnih sijela. Naše istraživanje pokazalo je smanjenje vrijednosti MPV-a u kasnim karcinomima grkljana. Pad MPV-vrijednosti kod naših ispitanika prati povećanje broja trombocita. Patofiziologija promjene volumena trombocita te uloga njihove aktivacije u malignim lezijama još uvijek nije u potpunosti objašnjena. Linkov F. i sur. opisuju paletu upalnih biomarkera koji su povišeni u kasnijim stadijima karcinoma grkljana. Osobito su interleukin 1 (IL-1) i interleukin 6 (IL-6) povezani s proliferacijom stanica planocelularnog karcinoma ${ }^{14}$. Upravo je IL-6 jedan od citokina koji se dovodi u vezu s aktivacijom trombocita i formi-

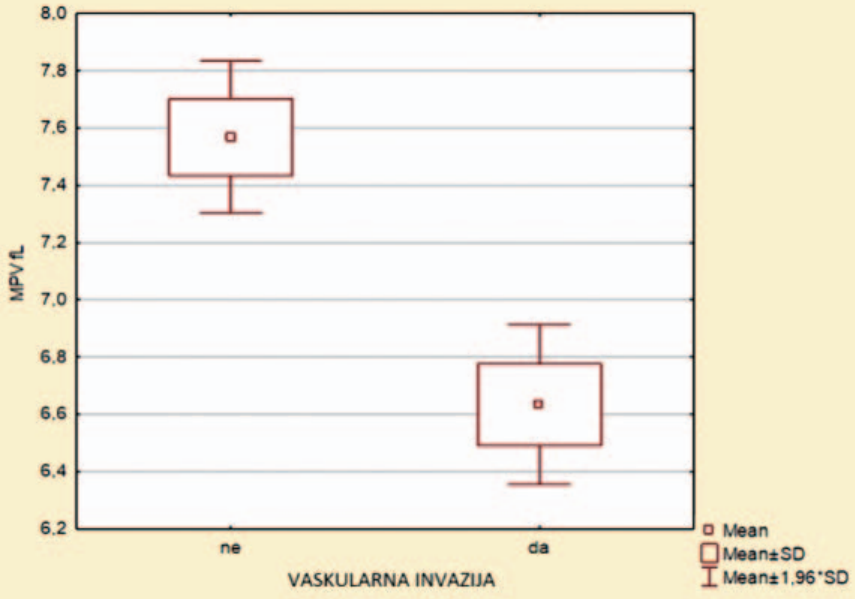

Slika 5. Usporedba vrijednosti MPV-a u skupinama pacijenata podijeljenim po podatku o vaskularnom invaziji karcinoma

ranjem ugrušaka u raznim upalnim stanjima ${ }^{15}$. Poznata je interakcija upalnih stanica u mikrokolišu tumora, a važnu ulogu u proizvodnji IL-6 imaju monociti. Gallo i sur. ističu kako same stanice tumora, ali i endotelne stanice novonastalih krvnih 
žila proizvode IL-6 ${ }^{16}$. S obzirom na to da je dokazana povećana razina IL-6 u krvi pacijenata s kasnim karcinomom grkljana, takvi rezultati govore u prilog mogućoj ulozi IL-6 u promjenama vrijednosti MPV-a pokazanim našim istraživanjem ${ }^{17}$. Kronična upala prati sve stadije karcinoma grkljana te je upravo ona važan uzrok hipoksije tumorskog tkiva. Hipoksiju tumora označava smanjenje parcijalnog tlaka kisika $\left(\mathrm{pO}_{2}\right)$ u tkivu tumora u odnosu na okolno zdravo tkivo ${ }^{18}$. Rezultat smanjene obskrbe kisikom je stvaranje novih krvinih žila.

Povećan broj trombocita kod karcinoma grkljana kasnog stadija prati smanjenje MPV-a. Dokazana je povezanost spomenutih vrijedosti s patohistološkim značajkama loše prognoze karcinoma, slabom diferencijacijom stanica i invazijom karcinoma u krvne žile.

Njihova stijenka je propusna i sklona spontanoj rupturi te pokreće kaskadu koagulacije ${ }^{19}$. Iz tog razloga MPV se koristi kao biomarker u praćenju pacijenata s karcinomom debelog crijeva u terapiji bevacizumabom, anti-VEGF (engl. anti-vascular endothelial growth factor) lijekom ${ }^{9}$. Osim VEGF-a kod karcinoma grkljana opisana je i uloga ostalih biomarkera, poput EGFR-a (engl. epidermal growth factor receptor), eritropoetina (EPO) i EPOR-a (eritropoetin receptor) ${ }^{18,20}$. EGFR je transmembranski protein koji ima ključnu ulogu u regulaciji staničnog ciklusa. Povećana ekspresija EGFR proteina i amplifikacija EGFR gena na 7. kromosomu dokazana je u kasnim karcinomima grkljana ${ }^{21,22}$. Nijkamp i sur. u svojoj studiji povezuju hipoksiju tumorskog tkiva i veću ekspresiju EGFR-a i njegovih liganda ${ }^{23}$. Potrebna su daljnja istaživanja kako bi se potvrdila veza ekspresije EGFR-a i neovaskularizacije, a tako i promjene u MPV-u i broju trombocita. Autokrina signalizacija stanica eritropoetinom opisana je kod lokalno invazivnih karcinoma grkljana. Terapija rekombinantnim eritropetinom povezuje se sa povećanim stvaranjem trombocita i varijacijama MPV-a $a^{24-26}$. Također, potrebna je potvrda utjecaja tumorskog eritropoetina na koštanu srž i produkciju trombocita. Hematogene mestaze karcinoma grkljana javljaju se u 7 \% pacijenata s kasnim karcinomom. Slaba diferencijacija stanica karcinoma i invazija u krvne žile smatraju se lošim prognostičkim znakom $^{27,28}$. Smanjenje MPV-a kod karcinoma s vaskularnom invazijom može značiti aktivnu koagulaciju na mjestima invazije ${ }^{29}$. Trombociti imaju važnu ulogu u hematogenom metastaziranju. Služe kao „štit“ za cirkulirajuće stanice metastatskog klona te parakrino inhibiraju limfocite i NK stanice, odnosno njihovo citotoksično djelovanje $^{30}$. Povećan broj trombocita dokazan ovim istraživanjem može govoriti u prilog toj tezi, ali je zbog smanjenog MPV-a upitna njihova funkcija i količina citoplazmatskih granula. Ipak, smanjenje MPV-vrijednosti kod slabo diferenciranih karcinoma i onih koji pokazuju vaskularnu invaziju ukazuje na moguće korištenje ovog parametra kao biomarkera karcinoma ${ }^{31,32}$. Potrebna je potvrda ovih rezultata istraživanjem na većem broju pacijenata, kao i prospektivno istraživanje s usporedbom preživljenja. Uz navedeno, nedostak ovog istraživanja je i nedostatak imunohistokemijskih metoda koje bi potvrdile sam mehanizam u patofiziologiji promjene MPV-a, što je u planu grupe autora u daljnjem istraživanju.

\section{ZAKLJUČCI}

Određivanje stadija i prognoze karcinoma grkljana često se temelji samo na TNM klasifikaciji i njegovim histološkim značajkama. U svrhu bolje dijagnostike, a zatim i terapije, nužno je uključiti što više biomarkera u svakodnevnu kliničku praksu. Ovim istraživanjem ukazujemo na mogućnost korištenja MPV-a upravo u te svrhe. Takva lako dostupna i jeftina pretraga kliničaru može ukazati na važne informacije o samom karcinomu, kao što su potvrda stadija i potencijano širenje bolesti te prognoza maligniteta.

Izjava o sukobu interesa: autori izjavljuju da ne postoji sukob interesa.

\section{LITERATURA}

1. Steuer E, El-Deiry M, Parks J, Higgins K, Saba N. An update on larynx cancer. Cancer J Clin 2017;67:31-50.

2. Hrvatski zavod za javno zdravstvo. Incidencija raka u Hrvatskoj 2013. Bilten br. 38. Zagreb: Hrvatski zavod za javno zdravstvo, 2015;1-34.

3. Brandstorp-Boesen J, Sorum Falk R, Boysen M, Brondo $\mathrm{K}$. Impact of stage, management and recurrence on survival rates in laryngeal cancer. PLoS ONE [Internet]. 2017;12. [cited 2018 May 20]. Available from: http:// doi.org/10.1371/journal.pone.0179371 
4. Park Woo J, Kim CH, Ha C, Young Kim M, Min Park S. Count of platelet and mean platelet volume score: serologic prognostic factor in patients with oral squamous cell carcinoma. J Korean Assoc Oral Maxillofac Surg 2017;43:305-11.

5. Rodrigues RB, Da Ros Motta R, Dos Santos Machado SM, Cambruzzi E, Zettler EW, Zettler CG et al. Prognostic value of the immunohistochemistry correlation of Ki-67 and p53 in squamous cell carcinomas of the larynx. Rev Bras Otorrinolaringol 2008;74:855-9.

6. Iovanescu GH, Poenaru M, Doros C, Boruga O. Histopathological prognostic and risk factors in patients with laryngeal neoplasms. Rom J Morphol Embryol 2013;54:1087-92.

7. Balkwill F, Mantovani A. Inflammation and cancer: back to Virchow? Lancet 2001;357:539-45.

8. Duzlu M, Karamert R, Tutar H, Sahin M, Turkacan A, Yilmaz M. Diagnostic role of neutrophil-lymphocyte ratio ino ral cavity cancer. Niger J Clin Pract 2018;21:49-53.

9. Mutlu H, Karakut Eryilmaz M, Musri F, Gunduz S, Salim D, Senol Coskun H. Mean platelet volume as an independent predictive marker for pathologic complete response after neoadjuvant chemotherapy in patients with locally advanced breast cancer. Asian Pac J Cancer Prev 2016;17:2089-92.

10. Li JY, Li Y, Jiang Z, Wang RT, Wang X. Elevated mean platelet volume is associated with presence of colon cancer. Asian Pac J Cancer Prev 2014;15:10501-4.

11. Zhang F, Chen Z, Wang P, Hu X, Gao Y, He J. Combination of platelet count and mean platelet volume (COP-MPV) predicts postoperative prognosis in both resectable early and advanced stage esophageal squamous cell cancer patients. Tumor Biol 2016;37:9353-61.

12. Gao L, Zhang H, Zhang B, Zhang L, Wang C. Prognostic value of combination of preoperative platelet count and mean platelet volume in patients with resectable nonsmall cell lung cancer. Oncotarget 2017;8:15632-41.

13. Eryilmaz A, Basal Y, Omurlu IK. Can head and neck cancers be detected with mean platelet volume? Asian Pac J Cancer Prev 2015;16:7045-7.

14. Linkov F, Lisovich A, Yurkovetsky Z, Marrangoni A, Velikokhatnaya L, Nolen B et al. Early Detection of Head and Neck Cancer: Development of a Novel Screening Tool Using Multiplexed Immunobead-Based Biomarker Profiling. Cancer Epidemiol Biomarkers Prev 2007;16:102-7.

15. Senchenkova EY, Komoto S, Russell J, Almeida-Paula LD, Yan S, Zhang S et al. Interleukin-6 Mediates the Platelet Abnormalities and Thrombogenesis Associated with Experimental Colitis. The American Journal of Pathology 2013;183:173-81.

16. Gallo O, Gori AM, Attanasio M, Martini F, Fini-Storchi O, Abbate R. Interleukin-6 serum level and monocyte production in head and neck cancer. Br J Cancer 1992;65:479-80.

17. Nikakhlagh S, Ranjbari N, Khorami E, Saki N. Association between Serum Levels of Interleukin-6 and Stage of Laryngeal Cancer. Iranian Journal of Otorhinolaryngology 2015;27:199-205.

18. Bredell MG, Ernst J, El-Kochairi I, Dahlem Y, Ikenberg K, Schumann DM. Current relevance of hypoxia in head and neck cancer. Oncotarget 2016; 7:50781-804.
19. Krock BL, Skuli N, Simon MC. Hypoxia-induced angiogenesis: good and evil. Genes Cancer 2011;2:1117-33.

20. Lin YT, Chuang HC, Chen $\mathrm{CH}$, Armas GL, Chen HK, Fang FM et al. Clinical significance of erythropoietin receptor expression in oral squamous cell carcinoma. BMC Cancer [Internet]. 2012;194. [cited 2018 May 20]. Available from: https://bmccancer.biomedcentral.com/articles/ 10.1186/1471-2407-12-194

21. Braut T, Kujundžić $M$, Vukelić J, Manestar D, Krstulja M, Starčević R, Grahovac B. Gene Amplification of Epidermal Growth Factor Receptor in Atypical Glottic Hyperplasia. Collegium antropologicum 2012;36:87-91.

22. Almadori G, Cadoni G, Galli J, Ferrandina G, Scambia G, Exarchakos $G$ et al. Epidermal growth factor receptor expression in primary laryngeal cancer: An independent prognostic factor of neck node relapse. Int J Cancer 1999;84:188-91.

23. Nijkamp MM, Span PN, Terhaard CHJ, Doornaert P, Langendijk JA, van den Ende $P$ et al. Epidermal growth factor receptor expression in laryngeal cancer predicts the effect of hypoxia modification as an additive to accelerated radiotherapy in a randomized controlled trial. Eur J Cancer 2013;49:3202-9.

24. Mohyeldin A, Lu H, Dalgard C, Lai SY, Cohen N, Acs et al. Erythropoietin Signaling Promotes Invasiveness of Human Head and Neck Squamous Cell Carcinoma. Neoplasia 2005;7:537-43.

25. Cases A, Escolar G, Reverter JC, Ordinas A, Lopez-Pedret $J$, Revert L et al. Recombinant human erythropoietin treatment improves platelet function in uremic patients. Kidney International 1992;42:668-72.

26. Tsompos C, Panoulis C, Toutouzas K, Triantafyllou A, Zografos $G$, Papalois A. The Acute Effect of Erythropoietin on Mean Platelet Volume Levels during Hypoxia Reoxygenation Injury in Rats. Med Bull Haseki 2016;54: 199-206.

27. Moe K, Wolf GT, Fisher S, Hong W. Regional metastases in patients with advanced laryngeal cancer. Arch Otolaryngol Head Neck Surg 1996;122:644-8.

28. Haemmerle M, Taylor ML, Gutschner T, Pradeep S, Cho MS, Sheng J et al. Platelets reduce anoikis and promote metastasis by activating YAP1 signaling. Nat Commun [Internet]. 2017;8. [cited 2018 May 20] Available from: https://www.nature.com/articles/s41467-017-00411-z

29. Pinedo HM, Verheul HMW, D'Amato RJ, Folkman J. Involvement of platelets in tumour angiogenesis? Lancet 1998;352:1775-7.

30. Leblanc R, Peyruchaud O. Metastasis: new functional implications of platelets and megakaryocytes. Blood 2016;128:24-31.

31. Tanriverdi O, Menekse S, Teker F, Oktay E, Nur Pilancı K, Gunaldi $M$. The mean platelet volume may predict the development of isolated bone metastases in patients with breast cancer: a retrospective study of the Young Researchers Committee of the Turkish Oncology Group (TOG). J BUON 2016;21:840-50.

32. Wang X, Cui MM., Xu Y, Liu L, Niu Y, Liu T et al. Decreased mean platelet volume predicts poor prognosis in invasive bladder cancer. Oncotarget 2017;8:68115-22. 